\title{
SÕNA CAPITAL SISALDAVATE INGLISKEELSETE MAJANDUSTERMINITE TÕLKIMISEST EESTI KEELDE
}

\author{
JAAN ALVER
}

Annotatsioon. Artikkel käsitleb inglise keelest eesti keelde tõlkimise probleeme sõna capital sisaldavate ingliskeelsete majandusterminite näitel. Vaadeldakse algselt ladina päritolu sõna kujunemist rahvusvaheliselt kasutatavaks paljude tähendustega adjektiiviks, substantiiviks ja verbiks. Antakse lühiülevaade capital' $\mathrm{i}$ kujunemisest majandusterminiks. Tuginedes Eestis ilmunud inglise-eesti erialasõnastikele, analüüsitakse põhjalikumalt mõnede olulisemate kahest sõnast koosnevate ingliskeelsete majandusterminite (nt capital goods, capital lease) eesti vastete sisu ja adekvaatsust.

Võtmesõnad: eesti keel, inglise keel, terminoloogia, tõlkimine, kapital

Artikkel tugineb autori pikaajalisele huvile turumajanduse oskussõnavara vastu, mis on tipnenud Briti ja Ameerika äriterminite (võrdlus)sõnastiku (Alver 1998) ja neljakeelse raamatupidamissõnastiku (Toots, Alver 2008) koostamisega. Käesoleva artikli kirjutamisel on kasutatud eestikeelsete allikate kõrval teistes riikides ilmunud kirjandust. Eriti palju kasu on olnud Suurbritannia (ODBW 1993; HFD 2007; OBED 2008 jt), USA(Friedman 2007 jt), Austraalia (Godfrey, Robb 1997; Renton 2008), Uus-Meremaa (Adam 1994), Kanada (TA 1992) ja Lõuna-Aafrika (Wuite 2009) autorite sõnastikest ja leksikonidest.

\section{Sissejuhatus}

Majanduse oskuskeele suhteliselt vähene rangus on üldtuntud. Meie poliitikute ja majandusteadlaste seas valitseb suur segadus turumajanduse ehk kõige olulisema termini - kapitali - tõlgendamisel ja kasutamisel. Oleme jõudnud niikaugele, et kapitaliks nimetatakse peaaegu kõike, mis pähe tuleb. Räägitakse põhikapitalist, käibekapitalist, aktsiakapi- 
talist, rahakapitalist, omakapitalist, lukratiivkapitalist, inimkapitalist, vaimsest kapitalist. Paljudes liitsõnades esineb kapital täiendsõnana. Nii võib kohata selliseid termineid nagu kapitalikaubad, kapitalikulud, kapitalikäive, kapitalitehingud, kapitaliturud jne. Seejuures on mainitud terminite kasutajate arvates tegemist eestikeelsete oskussõnadega, mille sisust kõik ülejäänud peavad täpselt niimoodi aru saama, nagu ühe või teise kirjatüki autor ise asja endale ette kujutab. Lähemal uurimisel aga selgub sageli, et ingliskeelsetest oskussõnadest pole nende kasutajad ise kas lõpuni või üldsegi mitte aru saanud ning otsetõlge eesti keelde on tihti vaid sisutühi sõnamulin. Kahjuks on sõna capital sisaldavate terminite ebatäpsed või suisa väärad tõlkevasted jõudnud ka seni ilmunud inglise-eesti (majandusterminite) sõnastikesse. Käesoleva artikli autori tähelepanekud näitavad, et capital'i kui majandustermini tekkimine, esialgne tähendus ja nüüdiskasutus on ebaselged ka neile, kelle emakeel on inglise keel. Mis siis veel rääkida nendest, kellele inglise keel on võõrkeel. Selle lünga kõrvaldamiseks ongi mõeldud käesolev artikkel.

\section{Kapital: üldkeelendist majandusterminiks}

Kapital on üks raskemini mõistetavaid, tõlgitavaid ja tõlgendatavaid sõnu. Etümoloogiliselt on kapital (inglise keeles capital) midagi, mis seotud tipuga. Kapital on algselt saadud ladina keelest:

caput ('pea') $\rightarrow$ capitālis ('peasse puutuv, peamine, väga hea, oivaline, suurepärane') $\rightarrow$ capitāle.

Traditsiooniliselt on pead loetud inimese tähtsaimaks kehaosaks. Seepärast ei tasu imestada, et paljudes keeltes (sh eesti keeles) on liitsõnu, mille üks osa (üldjuhul adjektiivi tähenduses) on pea. Sõnast pea on moodustatud näiteks peaasi 'peamine asi', peaasjalikult, aga ka peakorter, peastaap, peaettevõtja, peadirektor, peaspetsialist, peainsener, peaökonomist, peakonstruktor, peatehnoloog, pearaamatupidaja, peazootehnik, peaagronoom, peaarst, peakunstnik, peahoone, peauks, peatee, peajumal, peategelane, peakangelane.

Eesti teatmekirjanduses on kapitali läbi aegade defineeritud mitmeti. Enamasti on püütud sellele võõrsõnale anda majanduslikku sisu. Tabelis 1 on toodud valikuline kimp eesti sõnastikest ja leksikonidest pärinevaid märksõna kapital seletusi aastaist 1930-2009. 
Tabel 1. Märksõna kapital seletusi eesti teatmekirjanduses

\begin{tabular}{|c|c|}
\hline Allikas & Märksõna kapital seletus (definitsioon) \\
\hline VL 1930-1931 & 1) põhivarandus; 2) tüvi- ehk peamine raha \\
\hline VVS 1933 & 1) põhivarandus; 2) tüvi- ehk peamine raha \\
\hline EE 1934 & $\begin{array}{l}\text { 1) laenutatud ehk värbav rahasumma (merkantilistid, } \\
\text { K. Menger jt); 2) toodetud tootmisvahendid (A. Smith, } \\
\text { E. Böhm v. Bawerk jt) }\end{array}$ \\
\hline VMO 1935 & $\begin{array}{l}\text { 1) rahvamajanduslikus mõttes: tootmisvahendid, tööga } \\
\text { loodud hüvised, mis ei ole määratud otseseks tarbimiseks, } \\
\text { vaid edasiseks tootmiseks (masinad, vabrikuhooned, talu- } \\
\text { ehitised, liiklemisvahendid jm); 2) ettevõttes: igasugused } \\
\text { varad ja väärtused, mida ettevõte kasutab ise või laenutab } \\
\text { teistele kasumisaamise eesmärgiga (kinnis- ja vallas- } \\
\text { vara, kaubad, raha, väärtpaberid, nõudmised ja õigused } \\
\text { jm); 3) käitismajanduses bilansi passivapoolel näidatud } \\
\text { tegevuskapital, mis koosneb nii oma- kui ka võõrkapitalist }\end{array}$ \\
\hline $\begin{array}{l}\text { Haljaspõld } \\
1935\end{array}$ & $\begin{array}{l}\text { 1) rahvamajanduslikus mõttes: tootmisvahendid, tööga } \\
\text { loodud varad, mis ei ole määratud otsekoheseks tarbi- } \\
\text { miseks, vaid edaspidise tootmise võimaldamiseks, nt } \\
\text { masinad, vabrikuhooned, taluehitised, liiklemisvahendid } \\
\text { jne; 2) ettevõttes: käibivad varad, nt kinnis- ja vallasvara, } \\
\text { kaubad, raha, väärtpaberid, nõuangud jne }\end{array}$ \\
\hline EVS 1937 & 1) põhivarandus; 2) tüvi- ehk peamine raha \\
\hline ERL 1937 & $\begin{array}{l}\text { 1) eramajanduslikult: mingi ettevõtte rahalised vahendid, } \\
\text { päritolu järgi oma- ja võor- või laenkapital; 2) rahva- } \\
\text { majanduslikult: varad ja hüvised, mis ei teeni silma- } \\
\text { pilgu-tarbeid, vaid mis soodustavad ja hõlbustavad uute } \\
\text { varade valmistamist }\end{array}$ \\
\hline VE 1938 & $\begin{array}{l}\text { 1) rahvalikus tähenduses: kasvikut andev rahasumma; } \\
\text { 2) rahvamajanduslikus mõttes - inimesetöö ja loodus- } \\
\text { jõudude koostööl loodud majandamisvahendid, nende } \\
\text { toodetud hüviste kogum, mis on määratud mitte otseseks } \\
\text { tarbimiseks, vaid vahenditult uute hüviste loomiseks }\end{array}$ \\
\hline VL 1961 & $\begin{array}{l}\text { 1) majandamis- ja tootmisvahendid, toodetud hüviste } \\
\text { kogum; 2) kõnek protsenti andev rahasumma või üldse } \\
\text { rahasumma }\end{array}$ \\
\hline ENE 1971 & $\begin{array}{l}\text { väärtus, mis loob palgatööliste ekspluateerimise teel lisa- } \\
\text { väärtust }\end{array}$ \\
\hline
\end{tabular}




\begin{tabular}{|c|c|}
\hline VL 1981 & $\begin{array}{l}\text { 1) väärtus, mis loob lisaväärtust, tekib palgatööliste } \\
\text { ekspluateerimisel; 2) kõnek protsenti andev rahasumma } \\
\text { või üldse rahasumma; 3) põhivara, tagavara, varu }\end{array}$ \\
\hline MTABC 1985 & $\begin{array}{l}\text { inimtööjõu ekspluateerimise vahendusel lisaväärtust loov ja } \\
\text { sel teel isekasvav väärtus }\end{array}$ \\
\hline ENE 1989 & $\begin{array}{l}\text { väärtus, mis suureneb palgatööjõu ekspluateerimisel lisa- } \\
\text { väärtuse võrra }\end{array}$ \\
\hline ÕS 1999 & $\begin{array}{l}\text { 1) maj vara või varaline õigus, millest saab tulu; 2) ülek } \\
\text { rikkus, väärtus, varandus }\end{array}$ \\
\hline Mereste 2003 & $\begin{array}{l}\text { vara või varaline õigus, millest saab rahas väljendatavat } \\
\text { tulu ning mida saab kasutada lisaomandi või -vara loomi- } \\
\text { seks }\end{array}$ \\
\hline VS 2005 & $\begin{array}{l}\text { 1) maj äritegevuseks vajalikud majanduslikud ressursid, } \\
\text { tootmise põhivara; 2) kõnek (suurem) rahasumma, varan- } \\
\text { dus, rikkus }\end{array}$ \\
\hline VL 2006 & $\begin{array}{l}\text { vara või varaline õigus, millest saab rahas väljendatavat } \\
\text { tulu ning mida on võimalik kasutada lisaomandi või -vara } \\
\text { loomiseks }\end{array}$ \\
\hline ÕS 2006 & $\begin{array}{l}\text { 1) maj vara või varaline õigus, millest saab tulu; } \\
\text { 2) ülek rikkus, väärtus, varandus }\end{array}$ \\
\hline VE 2006 & $\begin{array}{l}\text { 1) kasvikut ehk intressi andev rahasumma; } 2 \text { ) inimtööga } \\
\text { loodud vahendid, mida kasutatakse uute hüviste tootmiseks }\end{array}$ \\
\hline TEARS 2006 & 1) äritegevuseks vajalik vara, raha vm vahendid; 2) väärtus \\
\hline MEVS 2008 & 1) maj tulu toov vara; 2) piltl väärtus, rikkus, varandus \\
\hline EKSS 2009 & $\begin{array}{l}\text { 1) maj vara või varaline õigus, millest saab tulu; } \\
\text { 2) (suurem) rahasumma; 3) piltl varandus; rikkus, väärtus }\end{array}$ \\
\hline VSM 2009 & $\begin{array}{l}\text { 1) maj äritegevuseks vajalikud majanduslikud ressursid, } \\
\text { tootmise põhivara, lähtevara; 2) kõnek (suurem) rahasumma, } \\
\text { varandus, rikkus }\end{array}$ \\
\hline
\end{tabular}

Selgelt võib märgata trükise ilmumise ajal kehtinud riigikorra või tsensuuri ning tollal valitsenud (oskus)sõnavara mõju. Nii on isegi ühe ja sama väljaande eri aastail ilmunud trükkides (nt VL 1961; VL 1981; VL 2006) märksõna kapital selgitatud isemoodi. Samas on kapitali mõistet seletatud erinevalt ka ühel ja samal aastal ilmunud teatmeallikates. Kuigi käesoleva artikli eesmärk ei ole märksõna kapital semantiline analüüs, peatume hetkeks 2008. aastal kirjastuse TEA üllitatud võõrsõnastikus 
(MEVS 2008) toodul. Pärast kapitali defineerimist tulu toova varana on toodud termini kapital kasutamise kohta järgmine näide: Kapitali hakati välja vedama. Esiteks, kapitali väljaveost räägiti viimati sovetiajal kapitalismi poliitilise ökonoomia loengutes. Tänapäeva majandusteadlased sellest ei räägi (poliitkorrektne on rääkida väliskapitali või veel parem, välisinvesteeringute sissetulekust), Google'i otsingumootor annab märksõna ainult Vikipeedia artiklis „Imperialism”, sedagi viitega Leninile. Teiseks, kapitali liikumine ei tähenda mitte vara, vaid eeskätt varalise õiguse liikumist - kapital tuleb varalise õigusena koos peremehe ehk kapitalistiga (füüsiliselt võib viimane asuda muidugi tuhandete kilomeetrite kaugusel). Seda rõhutati isegi sovetiaja loengutes ja tekstides. Kahjuks võib kohatist ebakompetentsust turumajanduslike märksõnade selgitamisel märgata kõigis pärast Eesti taasiseseisvumist publitseeritud eestikeelsetes teatmeallikates (eriti nendes, mille autorid ei ole majandusteadlased).

Inglise keeles oli capital algselt ainult adjektiiv (Capital: Word History), mille tähendus oli 'peamine, pea-, tähtsaim, suur' (need tähendused on säilinud ka tänapäeval). Seda kasutati sõnaühendeis eranditult koos substantiiviga, kusjuures viimane määras sõnaühendi $\mathrm{r}$ a k e n d u s l i k u t ä h e n d u s e. See on hästi jälgitav paljude mitmest sõnast koosnevate ingliskeelsete terminite puhul: capital city, capital letter, capital ship, capital goods, capital expenditure, capital idea jne (vt joonis 1).

Hiljem on paljud algselt kasutusel olnud sõnaühendid (nt capital city, capital letter, capital ship, capital goods) lühendatud lihtsalt capital'iks, nagu on näha ka jooniselt. Kuna capital hakkas niiviisi esindama terveid sõnaühendeid, mille rakendusvaldkond ja sisuline tähendus olid määratud substantiividega, muutus varem ainult adjektiivina kasutusel olnud sõna capital ka mitmetähenduslikuks substantiiviks. Niiviisi on tekkinud üsna ebaharilik olukord, kus ühel sõnal, mis on nii adjektiiv kui ka substantiiv, on õige palju tähendusi. Seepärast on sõna capital korrektseks tõlkimiseks inglise keelest vaja pöörata tähelepanu kontekstile. Kui kellelgi ei tule pähe hakata eesti keelde tõlkimisel pealinna, oivalist mõtet või suurt lahingulaeva kapitaliks nimetama, siis ingliskeelsetes majandustekstides esinev capital tõlgitakse eesti keelde peaaegu eranditult kui kapital. Seejuures ei pöörata tähelepanu sellele, kas capital esineb adjektiivina või substantiivina ja milline on konkreetses situatsioonis kasutatava konkreetse tähendusega sõna(ühendi) tegelik sisuline tähendus. Selle asemel, et asi 


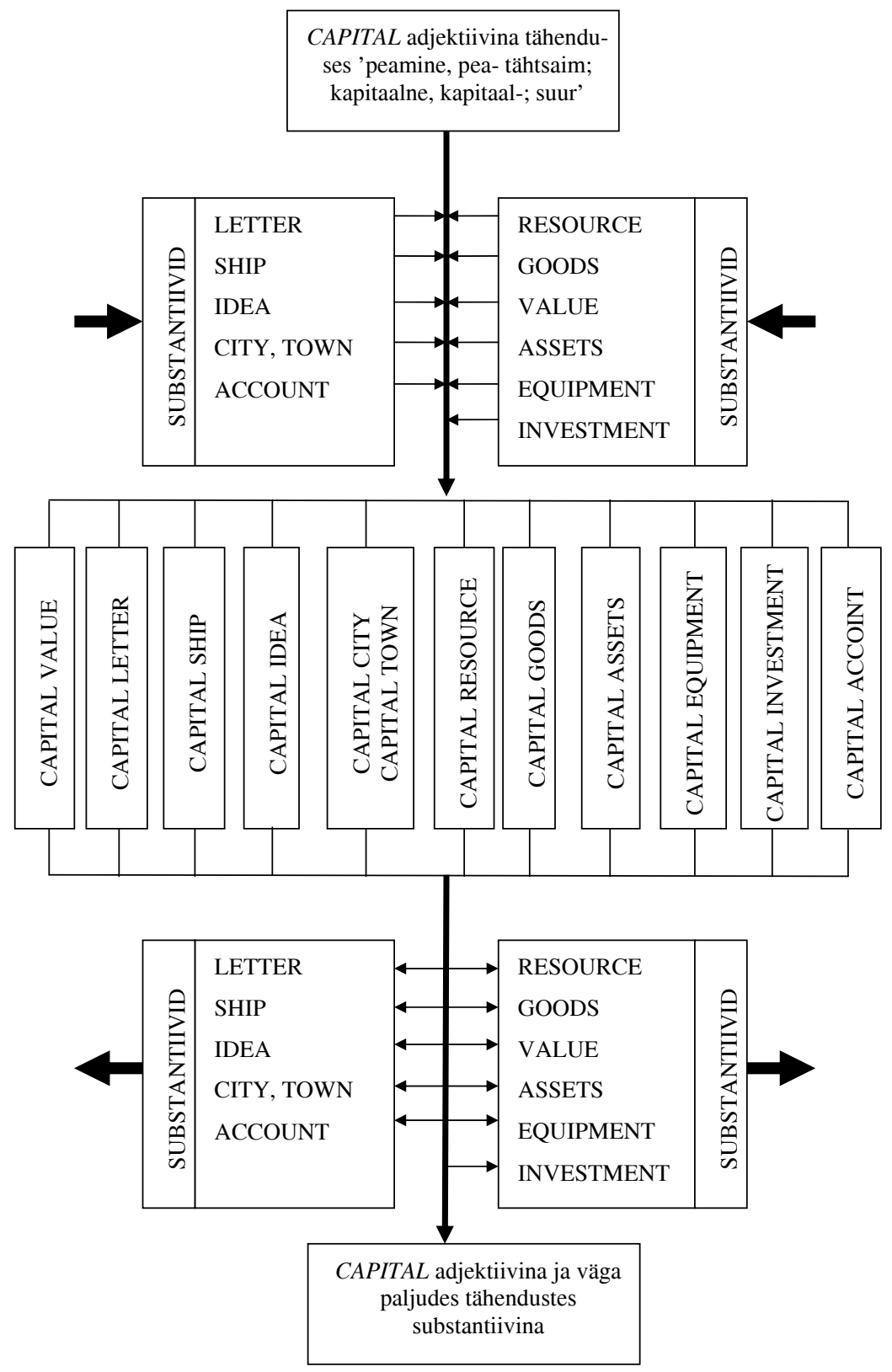

Joonis 1. Termini capital metamorfoosid 
sisuliselt selgeks teha, minnakse kõige primitiivsemat ja ebaõigemat toortõlkimise - teed.

\section{Kapital kui majandustermin}

Majandusterminina on kapitali defineeritud ja kasutatud valdkonniti väga paljudes tähendustes. Keskaja algul tähistati terminiga capitālis pars debiti laenu põhisummat (Cannan 1921: 470) vastandina kasvikusummale (fructus), hiljem aga iga kasvikut andvat rahasummat.

Ingliskeelsesse majanduskirjandusse ilmus capital (täpsemalt capitall) XVI sajandi teisel poolel, algul adjektiivina, XVII sajandil aga ka substantiivina (Capital: Word History). Professor Edwin Cannan on seisukohal, et majandusterminina hakati seda sõna kasutama kõigepealt raamatupidamise õpetamisel (Cannan 1921: 471). Raamatupidamisajaloolaste arvates on esimene ingliskeelne trükis, kus kasutati sõna capitall majandusterminina, inglise kaupmehe ja raamatupidaja James Peele'i 1569. aastal ilmunud raamat „The Pathe waye to Perfectness, in th'accompts of Debitour and Creditour" (Peele on ka termini capital stock - originaalis capital stockeesmakasutaja). Järgmised teadaolevad ingliskeelsed trükised, kus kasutati sõna capitall majandusterminina, on matemaatiku ja kooliõpetaja John Mellise 1588. aastal ilmunud raamat „A briefe instruction and maner how to keepe bookes of Accompts after the order of Debitor and Creditor" (Richards 1926: 331) ning raamatupidaja ja raamatupidamisõpetaja Richard Dafforne'i 1635. aastal ilmunud raamat „The Merchants Mirrour: or, Directions For the perfect Ordering and Keeping of his Accounts. Framed By way of Debitor and Creditor, after the (so tearmed) Italian Manner" (Richards 1926: 337). Laiemalt hakati Inglismaal capital'i majandusterminina kasutama XVII sajandi lõpust, mil see jõudis ka seadustikku (nt 1697. aastal vastu võetud Inglise Panga seaduses esineb termin capital stock). Capital'i kui ingliskeelse majandustermini ja selle sellest lähtuvate oskuskeelendite edasiarendajana on kõige rohkem tuntud kuulus šoti filosoof, ühiskonna- ja majandusteadlane Adam Smith ${ }^{1}$. Tema seisukohtade käsitlemine väljuks aga juba artikli teema piiridest.

Tänapäeval kasutatakse ingliskeelses majanduskirjanduses terminit capital järgmistes tähendustes (loetelu pole lõplik).

A. Smith on nüüdisaegse majandusteaduse ja liberaalse turumajanduse alusepanijaid. 


\section{Majandusteooria ${ }^{2}$ ja pangandus}

- vabrikud, masinad ja tootmisprotsessi muud inimeste loodud sisendid (Friedman 2007);

- vara, mis on võimeline tooma tulu ja mis ise on inimeste toodetud (Bannock jt 2003);

- $\quad$ vara (v.a maa ja tööjõud), mida vajatakse tootmiseks (LDFT 2008);

- tootmistegur, mida esindavad kõik kaubad ja mida kasutatakse teiste kaupade tootmiseks ja teenuste osutamiseks (BT 1991);

- tootmistegur, tavaliselt kas masinad ja seadmed (füüsiline kapital) või raha (finantskapital) (CDB 1991);

- miski väärtuslik, mis ettevõttel või organisatsioonil olemas on, nt masinad või raha, mida on võimalik kasutada jõukuse kasvatamiseks (OBED 2008);

- klassikalises ja neoklassikalises majandusteoorias üks kolmest tootmisprotsessi sisendist (peale kapitali veel ka maa ja tööjõud). Kapital koosneb toodetud püsikaupadest, mida korduvalt kasutatakse tootmises (Samuelson, Nordhaus 1989: 967).

\section{Rahandus ja investeeringud}

- ettevõttesse investeeritud või ettevõtte asutamiseks kasutatud rahasumma (OBED 2008);

- omaniku poolt ettevõttesse investeeritud raha (Brockington 1993);

- laenuks võetud või antud raha, millelt arvestatakse intressi (OBED 2008; ODBE 1993);

- investorite poolt äri alustamiseks panustatud raha (Wuite 2009; ODBE 1993);

- raha, mida eraisik või organisatsioon saab investeerida kasumi teenimiseks (DBM 2003);

- firma aineline koguvara (Davids 1986);

- $\quad$ vara koguväärtus (Wuite 2009);

- firma või usaldusühingu puhasvara, mis hõlmab algse investeeringu, kõik tulumid ${ }^{3}$ ja kasumid (Rosenberg 1993);

2 Käesolevas artiklis mõistetakse majandusteooria all seda valdkonda, mida inglise keeles tähistatakse terminiga economics.

3 Terminit tulum kasutati juba sõjaeelses Eesti Vabariigis, kus selle tähendus oli 'ülejääk'. Siin on tulum ingliskeelse termini gain eesti vaste. 
- ettevõtte omakapitali ja pikaajaliste kohustiste turuväärtus (Banks 2010).

\section{Äri}

- äritegevusse investeeritud raha (Rosenberg 1993);

- reaalvara väärtus, mis on väljendatud rahas (Adam 1993).

\section{Raamatupidamine}

- $\quad$ summa, mille võrra vara ületab kohustisi (Munn jt 1993; Rosenberg 1993; Siegel, Shim 2005);

- ettevõtte omandis oleva vara koguväärtuse ja tema kohustiste vahe (OBED 2008);

- ettevõttele kuuluva vara (maa, ehitised, masinad jne) koguväärtuse ja tema kohustiste vahe (ODBE 1993).

\section{Valdkond määramata}

- ettevõttesse pikaks ajaks investeeritud fondid (BT 1991);

- kaubad, mis on ostetud tootmises kasutamiseks (Siegel, Shim 2005);

- raha ja muud fondid, mida on võimalik ettevõttes kasutada (Mooney 2008);

- omaniku (kaas)osa ettevõttes (Davids 1986; TA 1992);

- firma puhasvara, k.a kasum (R. J. Shook, R. Shook 1990).

Kapitali kui majandusterminit on põhjalikult käsitlenud sõjaeelse Eesti Vabariigi ehk kõige andekam majandusteadlane (muidugi kui mitte arvestada 1929. aastal 21-aastasena Eestist lahkunud ja välismaal maailmakuulsust kogunud Ragnar Nurkset), eesti keele ja mitme võõrkeele perfektne valdaja Karl Inno ${ }^{4}$. Tuginedes maailmakuulsa majandusteadlase Joseph Alois Schumpeteri seisukohtadele, märgib Inno, et „enamiku

4 Karl Inno (1908-1994) andekusest ja mitmekülgsusest annavad tunnistust järgmised faktid. Ta oli kõigest 25-aastane, kui andis trükikojale üle oma esimese monograafia „Bilansianalüüs” käsikirja (ilmus 1935. aastal). Selles kasutas ta ulatuslikult saksa-, inglis-, prantsus- ja venekeelset erialakirjandust, vältides sisutühje toortõlkeid ja luues vajaduse korral uusi oskussõnu. Viimane asjaolu ilmestas Inno kogu lühikeseks jäänud õppejõu- ja teadlasekarjääri. Ta oli aastail 1938-1944 (aastase vaheajaga 1940-1941) Tartu Ülikoolis panganduse ja kindlustusasjanduse adjunktprofessor, 
kapitaliteooriate käsitusobjektiks on sama fenomen, sama probleem. Vaatamata fenomeni samasusele on kapitali mõiste siiski kujunenud tähtsaimaks tüliobjektiks majandusteaduses, eriti rahvamajandusteaduses (kuna käitismajandusteaduses esineb kaugelt suurem kapitali käsituse ühtlus)" (Inno 1938: 9).

\section{Kahest lihtsõnast koosneva liitsõna moodustamise semantilised alused}

Käesoleva artikli teema seisukohast pakuvad erilist huvi kahest sõnast (millest üks on capital) koosnevad ingliskeelsed majandusterminid, mille eesti tõlkevasted on liitsõnad. Eesti terminoloogilise liitsõnamoodustuse semantilisi aluseid on käsitlenud akadeemik Uno Mereste (2000b), kelle seisukohti järgnevalt lühidalt refereeritakse.

Kahe lihtsõna liitumisel jääb üks neist põhisõnaks (tähistame selle suurtähega $P$ ), teine täidab põhisõna täpsustava täiendsõna (T) ülesandeid. Eesti liitsõnades on põhisõna alati järelasendis ja täiendsõna eesasendis ${ }^{5}$, sest sõnad moodustatakse skeemi

$$
\mathrm{S}=(\mathrm{T}+\mathrm{P})
$$

alusel, kus T ja P on osis- ehk komponentsõnad, S on liitsõnamoodustuse seisukohalt vaadatuna tulemussõna ja märk + tähistab sõnade liitumist. Sulud () rõhutavad, et komponentsõnad $\mathrm{T}$ ja P esinevad kokkukirjutises just nimelt sellises järjekorras.

Liitsõnaliste majandusterminite moodustamine käib ja nende mõistesisu kujuneb üldjuhul põhimõtteliselt samasuguse loogilise struktuuri kohaselt nagu teistelgi liitsõnadel. Liitsõna moodustamine tähendab loogika mõisteõpetuse seisukohalt põhisõnaks muutuva iseseisva sõnaga tähistatava mõiste täpsustamist ehk determineerimist mingi, täiendsõna mõistes väljenduva tunnuse lisanemise kaudu.

kirjutas monograafiad „Pangandamistehnika” (1938) ning „Kontoraamistik ja kuluarvestus" (1942), jõudis avaldada hulga pangandust, finantsorganite ja ühistegevuslike asutuste tegevust käsitlevaid sisukaid teadusartikleid ning oli Akadeemilise Majandusteaduse Seltsi ajakirja Majandusteaduslik Ajakiri toimetajaid ja sõjaeelse Eesti suurima majandusteadusliku uurimistöö „Eesti krediidiühistud” (1940) toimetajaid ja koostajaid.

5 Mereste märgib (2000b), et sellest reeglist on mõningaid erandeid (nt sõjaväelistes auastmenimetustes). 
Eelmärgitust lähtudes saab sõna capital sisaldavate ingliskeelsete kahest sõnast koosnevate majandusterminite tõlkimiseks sõnastada järgmise reegli:

Kui capital on termini teine (resp. viimane) sõna, siis on ta substantiiv, kui aga esimene sõna, siis adjektiiv, mille eesti vaste ei ole kapital.

Järgnevas analüüsis ongi lähtutud sellest reeglist.

\section{Mõningate sõna capital sisaldavate kahesõnaliste ingliskeelsete majandusterminite tõlkimisest eesti keelde}

Turumajanduse ingliskeelsete oskussõnade eesti tõlkevastete analüüsimisel on artikli autor tuginenud Eestis aastail 1990-2007 ilmunud kaheksale majandussõnastikule, millest neli (IEMTS 1990; IEMTSS 1992; IERSS 1994; SIEMS 2003) on koostanud majandusteadlased ja neli (IEEIÄS 1993; IEMS 1995; UIEMS 1999; IEMSS 2007) keeleteadlased (vt tabel 2).

\subsection{Capital account}

See termin esineb vaadeldud kaheksast sõnastikust kuues. Inglise keeles on termin capital account kasutusel mitmes eri tähenduses, mis on üldistatult järgmised:

1. Majanduse makrotasemel tähistatakse selle terminiga riigi maksebilansi seda osa, kus on näidatud riikidevahelised pikaajalised investeeringud ja laenud ning tehingud Rahvusvahelise Valuutafondi ja teiste taoliste organisatsioonidega (Hammett 2001; Samuelson, Nordhaus 1989: 911-912; Steer 1990; Wallace, Flynn 1989).

2. Oxfordis ilmunud soliidne ärisõnastik märgib ühe võimalusena tähistada vaadeldava terminiga kontot, kus arvestatakse ainelise põhivara soetamisega seotud kulutusi (ODBW 1993). Analoogilisel seisukohal on ka teised autoriteetsed sõnastikud (Adam 1991; Wanjialin 2004). 
Tabel 2. Mõnede adjektiivi capital sisaldavate ingliskeelsete sõnaühendite eesti

\begin{tabular}{|c|c|c|c|c|}
\hline \multirow{2}{*}{$\begin{array}{l}\text { Ingliskeelne } \\
\text { termin }\end{array}$} & \multicolumn{4}{|c|}{ Eesti vasted ja nende allikad } \\
\hline & IEMTS 1990 & IEMTSS 1992 & IEEIÄS 1993 & IERSS 1994 \\
\hline $\begin{array}{l}\text { Capital } \\
\text { account }\end{array}$ & $\begin{array}{l}\text { kapitali } \\
\text { arvestus; } \\
\text { kapitali bilanss }\end{array}$ & $\begin{array}{l}\text { kapitalikäibe } \\
\text { bilanss, } \\
\text { kapitalibilanss }\end{array}$ & $\begin{array}{l}\text { kapitalikonto, } \\
\text { kapitaliarve; } \\
\text { kapitalikäibe } \\
\text { bilanss, kapita- } \\
\text { libilanss; põhi- } \\
\text { arve; kapitali } \\
\text { arvestus }\end{array}$ & - \\
\hline Capital asset(s) & - & $\begin{array}{l}\text { põhikapital, } \\
\text { põhivara }\end{array}$ & $\begin{array}{l}\text { põhikapital; } \\
\text { põhivahendid, } \\
\text { põhivara }\end{array}$ & $\begin{array}{l}\text { põhikapital, } \\
\text { põhivara }\end{array}$ \\
\hline $\begin{array}{l}\text { Capital } \\
\text { expenditure(s) }\end{array}$ & $\begin{array}{l}\text { kapitali- } \\
\text { kulutused, } \\
\text { kapitali- } \\
\text { mahutused }\end{array}$ & $\begin{array}{l}\text { kapitalimahu- } \\
\text { tused, kapitali- } \\
\text { kulud }\end{array}$ & - & $\begin{array}{l}\text { kapitaal- } \\
\text { mahutused, } \\
\text { kapitalikulu }\end{array}$ \\
\hline Capital gain(s) & $\begin{array}{l}\text { lisaväärtus } \\
\text { (ains), tulem } \\
\text { põhifondide } \\
\text { müügist (mitm) }\end{array}$ & $\begin{array}{l}\text { tulu kapitali- } \\
\text { kasvust, } \\
\text { kapitali kasvu- } \\
\text { tulu }\end{array}$ & $\begin{array}{l}\text { kapitalikasvu- } \\
\text { tulu, kapita- } \\
\text { livõit; tulem } \\
\text { põhivahendite } \\
\text { müügist }\end{array}$ & - \\
\hline Capital loss & $\begin{array}{l}\text { kapitali müü- } \\
\text { gist saadud } \\
\text { kahjum }\end{array}$ & $\begin{array}{l}\text { kapitali kaotus, } \\
\text { kapitali kadu, } \\
\text { kapitali vähe- } \\
\text { nemine }\end{array}$ & $\begin{array}{l}\text { kapitalikas- } \\
\text { vukahjum, } \\
\text { kapitalikaotus; } \\
\text { kahjum }\end{array}$ & $\begin{array}{l}\text { kapitali kaotus, } \\
\text { kapitali kadu, } \\
\text { kapitali vähene- } \\
\text { mine }\end{array}$ \\
\hline Capital goods & $\begin{array}{l}\text { tootmis- } \\
\text { vahendid }\end{array}$ & $\begin{array}{l}\text { kapitalikaubad, } \\
\text { investeerimis- } \\
\text { kaubad }\end{array}$ & $\begin{array}{l}\text { kapitalikaubad, } \\
\text { investeeri- } \\
\text { miskaubad; } \\
\text { põhivahendid, } \\
\text { tootmisvahen- } \\
\text { did }\end{array}$ & $\begin{array}{l}\text { kapitalikaubad, } \\
\text { investeerimis- } \\
\text { kaubad }\end{array}$ \\
\hline Capital lease & - & $\begin{array}{l}\text { kapitali } \\
\text { rendile- } \\
\text { andmine, kapi- } \\
\text { tali rentimine }\end{array}$ & $\begin{array}{l}\text { kapitali renti- } \\
\text { mine, kapital- } \\
\text { iseeritud rent }\end{array}$ & kapitalirent \\
\hline Capital stock & $\begin{array}{l}\text { põhikapital, } \\
\text { aktsiakapital }\end{array}$ & - & $\begin{array}{l}\text { aktsiakapital, } \\
\text { põhikapital }\end{array}$ & $\begin{array}{l}\text { aktsiakapital, } \\
\text { põhikapital }\end{array}$ \\
\hline
\end{tabular}


vasteid Eestis publitseeritud sõnastikes

\begin{tabular}{|c|c|c|c|}
\hline \multicolumn{4}{|c|}{ Eesti vasted ja nende allikad } \\
\hline IEMS 1995 & UIEMS 1999 & SIEMS 2003 & IEMSS 2007 \\
\hline kapitalikonto & $\begin{array}{l}\text { kapitalikäibe } \\
\text { bilanss; finants- } \\
\text { konto }\end{array}$ & $\begin{array}{l}\text { kapitalikonto, finants- } \\
\text { konto; põhiarve }\end{array}$ & - \\
\hline $\begin{array}{l}\text { kapitaalvara, põhi- } \\
\text { vara, mittelikviidsed } \\
\text { aktivad; kinnisvara }\end{array}$ & $\begin{array}{l}\text { (põhi)kapital, } \\
\text { kapitaalvara }\end{array}$ & $\begin{array}{l}\text { põhivara, mitte- } \\
\text { likviidsed aktivad; } \\
\text { kinnisvara }\end{array}$ & $\begin{array}{l}\text { 1) põhivara; } \\
\text { 2) mittelikviidsed } \\
\text { aktivad }\end{array}$ \\
\hline $\begin{array}{l}\text { kapitaalmahutused, } \\
\text { investeeringud; } \\
\text { kapitalikulu }\end{array}$ & $\begin{array}{l}\text { kapitalimahutused, } \\
\text { investeeringud, } \\
\text { kapitalikulutused }\end{array}$ & $\begin{array}{l}\text { kapitaalmahutused, } \\
\text { investeeringud; } \\
\text { kapitalikulu, kapitali } \\
\text { kulutamine }\end{array}$ & $\begin{array}{l}\text { 1) kapitalimahu- } \\
\text { tus, investeering; } \\
\text { 2) ettevõttesse } \\
\text { mahutatud kapital }\end{array}$ \\
\hline $\begin{array}{l}\text { põhivara } \\
\text { realiseerimiskasum, } \\
\text { põhivara müügitulu }\end{array}$ & $\begin{array}{l}\text { tulu kapitalikas- } \\
\text { vust, kapitali } \\
\text { kasvutulu; põhivara } \\
\text { müügitulu }\end{array}$ & $\begin{array}{l}\text { põhivara realiseerimis- } \\
\text { kasum, põhivara } \\
\text { müügitulu; kapitali- } \\
\text { võit, kapitalikasvutulu }\end{array}$ & $\begin{array}{l}\text { tulu kapitalikas- } \\
\text { vult, kapitali } \\
\text { kasvutulu }\end{array}$ \\
\hline $\begin{array}{l}\text { kahjum põhivahendite } \\
\text { müügist, põhivara } \\
\text { realiseerimiskahjum }\end{array}$ & $\begin{array}{l}\text { suur kahju/kah- } \\
\text { jum; kapitalikadu, } \\
\text { kapitalikaotus, kapi- } \\
\text { tali vähenemine }\end{array}$ & $\begin{array}{l}\text { kahjum põhivahendite } \\
\text { müügist, põhivara } \\
\text { realiseerimiskahjum; } \\
\text { kapitalikaotus }\end{array}$ & $\begin{array}{l}\text { kapitali } \\
\text { vähenemine }\end{array}$ \\
\hline $\begin{array}{l}\text { investeerimiskaubad } \\
\text { (tootmisvahendid), } \\
\text { reaalpõhikapital }\end{array}$ & $\begin{array}{l}\text { kapitalikaup, } \\
\text { investeerimiskaup } \\
\text { (tootmisvahendid); } \\
\text { reaalpõhikapital }\end{array}$ & $\begin{array}{l}\text { kapitalikaubad, } \\
\text { investeerimiskaubad } \\
\text { (tootmisvahendid), } \\
\text { reaalpõhikapital, põhi- } \\
\text { vahendid }\end{array}$ & $\begin{array}{l}\text { investeerimis- } \\
\text { hüvised, } \\
\text { kapitalihüvised }\end{array}$ \\
\hline $\begin{array}{l}\text { kapitaalrentimine, } \\
\text { kapitaalne rentimine }\end{array}$ & $\begin{array}{l}\text { kapitali/aktivate } \\
\text { rendileandmine, } \\
\text { kapitali rentimine, } \\
\text { kapitaliliising, } \\
\text { finantsliising }\end{array}$ & $\begin{array}{l}\text { kapitali rentimine, } \\
\text { kapitali rendile- } \\
\text { andmine }\end{array}$ & kapitali rentimine \\
\hline $\begin{array}{l}\text { (US) aktsiakapital; } \\
\text { (UK) organisatsiooni } \\
\text { põhivara kogu- } \\
\text { summa }\end{array}$ & $\begin{array}{l}\text { Am aktsiakapital; } \\
\text { Br ettevõtte põhi- } \\
\text { vara, põhikirjafond }\end{array}$ & $\begin{array}{l}\text { Br (organisatsiooni) } \\
\text { põhivara kogusumma; } \\
\text { põhikapital; Am akt- } \\
\text { siakapital }\end{array}$ & põhikapital \\
\hline
\end{tabular}


3. Peaaegu kõigis ingliskeelsetes teatmeteostes ja majandusarvestuse õpikutes leiab kajastamist seisukoht, et majanduse mikrotasemel tähistatakse terminiga capital account kontot, mis näitab omaniku osa (omakapitali) ettevõttes (Brockington 1993; Crumbley jt 1994; Friedman 2007; Wanjialin 2004; Rosenberg 1986; R. J. Shook, R Shook 1990; ODBW 1993; Wallace, Flynn 1989).

Olgu märgitud, et sõnaühendina on capital account erand, kus capital ei esine adjektiivi tähenduses ja otsetõlge kapitalikonto on igati korrektne. Nii on see ka saksa, prantsuse, itaalia ja hispaania keeles (BCCSLBD 1991; Ricci 1990). Ebasoovitatav tõlkevaste on kapitaliarve, mis võib põhjustada vääritimõistmist (vrd restoraniarve, hotelliarve, elektriarve). Ei sobi ka põhiarve ega kapitali arvestus. Termini capital account kui maksebilansi osa tõlkevasted kapitalibilanss ja kapitali bilanss on sisult väärad. Ingliskeelsete terminitega balance of payments (maksebilanss) ja capital account tähistatavate objektide suhetest on hästi kirjutanud kuulus USA majandusteadlane, Nobeli majanduspreemia laureaat Paul Anthony Samuelson (Samuelson, Nordhaus 1989: 911-912), kes märgib, et maksebilanss nagu igasugune bilanss on alati tasakaalus ${ }^{6}$. Erinevalt maksebilansist kui tervikust pole capital account tasakaalustatud. Veel märgib Samuelson, et capital account'i puhul rakendatakse kahekordse kirjendamise (double entry) põhimõtet, st et capital account nagu teisedki kontod on deebeti- ja kreeditipoolega ning deebet- ja kreeditkäibe vahe tuuakse välja saldona (balance on capital account), mis võib olla nii pluss- kui ka miinusmärgiga (Samuelson, Nordhaus 1989: 912). Samuelson toob ära ka USA maksebilansi, kus capital account'i kohta on näidatud deebetkäive, kreeditkäive ja saldo (Samuelson, Nordhaus 1989: 912). Analoogilisel seisukohal on ka teised majandusteadlased. Seega capital account ei ole bilanss, vaid konto! Muuseas, väärvaste kapitalibilanss kasutamisel tekib ka tõsiseid semantilisi probleeme. Kui capital account oleks kapitalibilanss, siis kuidas tõlkida balance on capital account või capital account balance? Kapitalibilansi saldo, kapitalibilansi jääk? Ainuõige on kapitalikonto saldo. Ebakorrektsete vastete kapitalikäibe bilanss, kapitalibilanss ja kapitali bilanss puhul on ilmselt tegu saksa

${ }^{6}$ Collinsi ärisõnastikus (Wallace, Flynn 1989) märgitakse maksebilansi kohta, et see on a country's balance sheet. Termini balance sheet eesti vaste on teatavasti raamatupidamisbilanss. 
termini (Kapitalverkehrsbilanz, Kapitalbilanz) mehaanilise ülevõtmisega ingliskeelse termini eesti vasteks.

\subsection{Capital asset(s)}

See termin esineb vaadeldud kaheksast sõnastikust seitsmes. Capital on selles sõnaühendis adjektiiv, seega otsetõlge oleks kapitaalne vara ehk kapitaalvara, mida võiks parema vaste puudumisel kasutada. Tõlkevaste põhivara kasutamisega tuleks olla ettevaatlik. Esiteks, paljud majandusteadlased on seisukohal, et terminiga capital assets tähistatavad varaobjektid on kindlasti ainelised (Rosenberg 1986; R. J. Shook, R. Shook 1990; Steer 1990; Wanjialin 2004), kuigi enamus seda seisukohta ei jaga. Teiseks, eesti keeles puuduvad selliste (suures osas kattuvate) ingliskeelsete terminite nagu long-term assets; long-lived assets; capital asset(s); fixed assets; plant assets; property, plant and equipment üldtunnustatud vasted. Enamik soliidseid välisautoreid ei samasta neid, vähemalt mitte kõiki. Oleks tarvis selgusele jõuda eelmärgitud ingliskeelsete terminite sisus ja omavahelistes suhetes ning seejärel otsustada, millised neist tõlkida eesti keelde kui põhivara, millised mitte. Mõtlemisainet annab ka puhtsemantiline küsimus: miks just põhi(vara)? Kas seda mõista tähenduses 'põhiline vara' või 'vara, millega ettevõttele põhi (resp. alus) pandi'? Ebakorrektne on kapitaalvara.

Capital asset(s)'i teine sõnastikes toodud vaste põhikapital pole õige, sest nagu juba märgitud, on selles sõnaühendis capital adjektiiv. Huvitav, et keegi pole soovitanud vaadeldavat terminit eesti keelde tõlkida kui kapitalivara. Analoogid (ebakorrektsed) on ju olemas (vt tabel 2): capital goods - kapitalikaubad; capital gain - kapitalivõit, kapitalikasu; capital loss - kapitali kaotus, kapitali kadu; capital lease - kapitalirent; capital expenditure(s) - kapitalikulu(d), kapitalikulutused. Ka ebakorrektsuses tuleks olla lõpuni järjekindel!

\subsection{Capital expenditure(s)}

See termin esineb vaadeldud kaheksast sõnastikust seitsmes. Eraldi tuleb peatuda raamatupidamissõnastikus toodud selgitusel: põhi- ja käibekapitali omandamiseks tehtud kulutused. Seega kapitalikulu on (põhi- ja käibe)kapitali omandamiseks tehtud kulutused. Totramat seletust on raske 
välja mõelda. Mis on siiski antud juhul kapital? Kas see, mida kulutati, või see, mis omandati? Või hoopis mõlemad ${ }^{7}$ ? Mida tegelikult kulutati ja mille tarvis? Kuna tegu on raamatupidamissõnastikuga, jääb segaseks, kus paikneb raamatupidamisbilansis see, mida kulutati, ja kus see, mis asemele saadi.

Vaadeldavas sõnaühendis on capital adjektiiv ning termini capital expenditure(s) eesti vasteks kõlbaks ka vana hea kapitaalmahutus(ed), kuid mitte kapitalimahutus(ed) ega kapitalikulutus(ed). Asi on nimelt selles, et kapitalimahutus võib olla nii pika- kui ka lühiajaline (ajutise iseloomuga), ingliskeelse capital expenditure(s) puhul on tegemist aga ainult pikaajalise, tõesti suure ehk kapitaalse mahutamisega (tavaliselt ainelise põhivara soetamisega). Selles on ühel nõul nii Briti (HFD 2007; DF 1993; CDB 1991; OBED 2008; ODBW 1993; Steer 1990) kui ka Ameerika (Munn jt 1993; Siegel, Shim 2005; Downes, Goodman 2006) autorid.

\section{Kapitalimahutus on sisult palju laiem kui kapitaalmahutus, hõlmates viimase.}

Siinkohal tahaks peatuda veel ühel asjaolul. Torkab silma, et ingliskeelsete terminite eesti vasteteks on rakendatud saksa termineid. Inglise-saksa ja saksa-eesti sõnastike kasutamises pole iseenesest midagi halba. Tuleb aga arvestada, et siin varitseb saksakeelsete terminite puuduste eesti keelde ülekandumise oht (nn katkise telefoni efekt). Näiteks ei ole juhtunud ingliskeelse majanduskirjanduse märksõnaregistrites nägema niisugust sõnaühendit nagu capital spending, mis on kolmes vaadeldud sõnastikus (IEMTSS 1992; IERSS 1994; UIEMS 1999) toodud kui capital expenditure(s)'i sünonüüm. Siinkirjutaja on palunud mainitud sõnaühendi kohta selgitust nii inglise keelt emakeelena kui ka inglise keelt võõrkeelena kasutatavatelt majandusteadlastelt, mille peale on ainult käsi laiutatud ja vastatud, et inglise keeles sellist sõnaühendit majandusterminina harilikult ei kasutata. Küll võib seda kohata aga Saksamaal ilmunud inglise-saksa rahandussõnastikus termini capital expenditure(s) sünonüümina (Schäfer 1990). Sõnaühendit capital spending saaks põhimõtteliselt inglise keeles kasutada, kuid siis tähenduses 'suur kulutus' või 'suur väljaminek'. Kapitaliga pole siin midagi tegemist. Kui jutt on lihtsalt raha väljaminekust,

Sel juhul saaks rääkida ainult kapitali transfereerimisest. 
öeldakse money spending. Kulutatakse raha, mitte kapitali! See seisukoht on leidnud selge kajastuse näiteks autoriteetses ärisõnastikus (Adam 1993), kus capital expenditure on defineeritud kui $\mathrm{r}$ a h a, mis on kulutatud põhivara ja materjalide soetamiseks.

\subsection{Capital gain(s)}

Imelikul kombel puudub see raamatupidamise jaoks äärmiselt oluline termin raamatupidamissõnastikust. Nagu tabelist 2 näha, on igal eesti autoril oma tõlkevasted. Ingliskeelsetes allikates on seda terminit defineeritud mitmeti:

- soetatud ainelise põhivara müügist saadud (vahe)kasu (Rosenberg 1986);

- $\quad$ soetatud põhivara (k.a väärtpaberid) müügist saadud (vahe)kasu (Samuelson, Nordhaus 1989; Bannock, Manser 1990; TA 1992; Caruth, Stovall 1994);

- $\quad$ soetatud vara müügist saadud (vahe)kasu (Pass jt 1991);

- tulum põhivara müügist (Crumbley jt 1994);

- summa, mille võrra põhivaraobjekti müügilaekum ületab tema bilansimaksumuse (Scott 2009);

- finantstulum, mida saadakse varaobjekti võõrandamisel (DBM 2003).

Seega osa autoreid laiendab termini capital gain $\mathrm{kog} \mathrm{u} \mathrm{varale,} \mathrm{sel}$ ajal kui teised seostavad seda ainult ainelise põhivaraga. Sõnastikes leiduv eestikeelne kapitalikasvutulu (kapitali kasvutulu, tulu kapitali kasvult) on küll lühike ja lööv, jääb aga sisutühjaks:

- pole selge, mida mõistetakse antud juhul kapitalina (kas kajastub raamatupidamisbilansi aktivas või passivas);

- pole selge, mis on kapitalikasv (kapitali kasv) ja kuidas sellelt tulu saadakse;

- kapitalikasu ja kapitalivõit on lihtsalt sisutühjad abstraktsed liitsõnad.

Käesoleval juhul ei tasuks sobiva tõlkevaste otsimisel kramplikult kinni hoida sõnast capital. 


\subsection{Capital loss}

See termin esineb kõigis kaheksas sõnastikus. Erinevalt eelmisest terminist on capital loss võetud raamatupidamissõnastikku. Kuna capital gain ja capital loss on antonüümid, on ka märkused suures osas ühesugused. Kapitali kadu, kapitalikaotus ja kapitali kaotus on mõttetud moodustised (huvitav, kes mida ja kuidas ära kaotas?). Absurdse liitsõnaloome musternäide on kapitalikasvukahjum. Kapitali müügist saadud kahjum võib esmapilgul tunduda korrektsena, ent on sisult täiesti väär. Ei ole juhtunud majanduskirjanduses lugema kapitali müümisest (selling of capital). Küll on võimalik müüa ja osta vara või põhivara. Termini capital loss puhul on mõttetu rääkida ka kapitali turuväärtusest ja selle vähenemisest, nagu mõnikord tehakse (IERSS 1994). Esiteks pole selge, mida mõista antud juhul kapitali all. Teiseks, kapitali turuväärtusest oleks teoreetiliselt mõeldav rääkida seoses raamatupidamisbilansi passivapoolega, kus kajastatakse omakapitali (owners' equity). Just nii püüaksid meie kodukootud terminit kapitali turuväärtus lahti mõtestada lääne majandusteadlased. Ent nemad kasutavad sel puhul hoopis teisi termineid (nt aktsia turuhind või turuväärtus). Inglise keeles on kasutusel termin market value of the enterprise (ettevõtte turuväärtus), mis hõlmab nii ettevõtte võõrkapitali (võlgu) kui ka omakapitali.

Analoogiliselt terminiga capital gain rakendatakse praktikas terminit capital loss peamiselt ainelise põhivara suhtes ning selle eesti vaste võiks olla põhivara võorandamiskadum või kadum põhivara võõrandamisest ${ }^{8}$.

\subsection{Capital good(s)}

See termin esineb kõigis vaadeldavates inglise-eesti sõnastikes, kuid tuleb märkida, et tema põhiline kasutusvaldkond on majandusteooria (economics). Neljas sõnastikus toodud tõlkevaste kapitalikaubad on täiesti absurdne, nii sisult kui ka keeleliselt ebakorrektne. Capital on vaadeldavas sõnaühendis adjektiiv, seega otsetõlge ei oleks mitte kapitalikaubad, vaid kapitaalsed ehk kapitaalkaubad. Viimast võiks parema vaste puudumisel eesti keeles kasutada eeldusel, et capital goods hõlmab ainult tootmis-

${ }^{8}$ Süvenemata ettevõttemajanduse oskussõnavarasse olgu märgitud, et ingliskeelse termini gain antonüümi tähenduses ei ole termini loss eesti vaste kahjum, kuna see ei vasta kahjumi definitsioonile (ei teki tulu ja kulu vahena). 
otstarbelisi kestvuskaupu, nagu märgitud mõnedes allikates (Brockington 1993; Caruth, Stovall 1994; Pass jt 1991; Samuelson, Nordhaus 1989). Majandusteoorias (economics) on capital goods lühendatult capital ja esineb t o otmistegurina, seda ei kulutata millegi omandamiseks. Kahjuks ei ole ingliskeelses erialakirjanduses ühtset seisukohta. Paljudes allikates märgitakse, et termin capital goods hõlmab ka materjale (CDB 1991; Davids 1986; Steer 1990; Adam 1991; ODBW 1993), osa majandusteadlasi aga tähistab selle terminiga varaobjekte (või kaupu), mida kasutatakse kaupade valmistamiseks (või teenuste osutamiseks), jättes täpsustamata, millistest varaobjektidest (kaupadest) on jutt (Downes, Goodman 2006; Friedman 2007; LDFT 2008; Renton 2008; R. J. Shook, R. Shook 1990). Sellisel juhul võiks tõlkevastena kõne alla tulla tootmisvahendid, mis on ühe võimaliku vastena toodud kahes vaadeldud sõnastikus (IEMTS 1990; IEEIÄS 1993) ja antud täpsustusena veel kahes (IEMS 1995; SIEMS 2003). Ärisõnastikus (IEEIÄS 1993) märgitud vaste põhivahendid praegusel juhul ei kõlba. Täiesti mõttetud liitsõnad on reaalpõhikapital (IEMS 1995; UIEMS 1999), investeerimishüvised ja kapitalihüvised (IEMSS 2007).

Capital goods ja capital equipment ei ole sünonüümid, nagu ekslikult märgitakse kolmes sõnastikus (IEMTSS 1992; IERSS 1994; UIEMS 1999). Capital equipment hõlmab masinaid ja seadmeid, kuid mitte hooneid, rajatisi ja materjale (Brockington 1993), olles seega oluliselt kitsama tähendusega kui capital goods.

Ingliskeelne sõna goods on harilikult eesti keelde tõlgitud kui kaubad. See aga ei tähenda, et igas sõnaühendis peaks goods'i ainuvaste olema kaubad. Näiteks ühendit goods in process pole veel keegi soovinud tõlkida lõpetamata kaupadeks, vaid ikka kui lõpetamata toodang või lõpetamata tooted.

\subsection{Capital lease}

See termin esineb vaadeldud kaheksast sõnastikust seitsmes, kusjuures kõik eesti vasted on ebakorrektsed. Capital on selleski sõnaühendis adjektiiv, seega otsetõlge oleks kapitaalne rentimine või kapitaalrentimine, mida parema vaste puudumisel võiks majandusterminina kasutada. Omal ajal professor Erik Linnaksi pakutud kapitalirent on väär, kuna selle liitsõna mõlemad pooled on tõlgitud ebakorrektselt: adjektiivist capital 
on tehtud substantiiv ning rentimine (liisimine, liising) on lühendatud rendiks. Viimast on harilikult kasutatud rendimakse tähenduses ${ }^{9}$. Kapitali rendileandmine (IEMTSS 1992; UIEMS 1999; SIEMS 2003) ja kapitali rentimine (IEMTSS 1992; IEEIÄS 1993; UIEMS 1999; SIEMS 2003; IEMSS 2007) on mõlemad väärvasted. Esiteks: kapitali ei rendita. Teiseks: oletame, et kapitalina on antud juhul mõistetud vara. Kuid vara rentimisega on tegu nii kapitaalrentimise kui ka kasutusrentimise (operating lease) puhul. Seega vara rentimine on palju laiema tähendusega kui kapitaalrentimine. Olgu veel märgitud, et majandusterminite seletussõnaraamatus (IEMSS 2007) on termini capital lease sisuseletus ebakorrektne.

Huvitav on amerikanismi capital lease saamislugu. Selle termini esialgne variant oli capitalized lease ehk kapitaliseeritav rent(imine), mille lühendamisel saadi capital lease ${ }^{10}$. Olgu märgitud, et ettevõttemajanduse erialakirjanduses tähendab kapitaliseerimine (capitalization) raamatupidamisbilansis kajastamist, millel pole midagi pistmist kapitaliga.

\subsection{Capital stock}

See termin esineb vaadeldud kaheksast sõnastikust seitsmes. Selleski sõnaühendis on capital adjektiiv. Seega rangelt süntaksist lähtudes tuleks eesti vasted põhikapital ja aktsiakapital lugeda ebakorrektseks, kuna mõlemas on kapital substantiiv. Vaadeldava termini tõlkimisel on aga veel ka muid probleeme, millest lähemalt allpool.

Ameerika inglise keeles tähistatakse tavaliselt sõnaga stock kellegi (üksikisiku, grupi, äriühingu) omandis olevate aktsiate koguhulka, aktsiapakki, kus teoreetiliselt võib olla ka ainult üks aktsia (share). Terminiga capital stock tähistavad ameeriklased nii aktsiaseltsi aktsiate koguhulka kui ka sellega adekvaatset aktsiakapitali (esineb raamatupidamisbilansi passivapoolel). Miks see nii on, võib ainult oletada. Briti termin aktsiakapitali tähistamiseks on share capital ${ }^{11}$, mille Ameerika inglise keele

${ }_{9}$ Sõjaeelses Eestis kasutatud termin rendis on tänapäeva majandusleksikast kahjuks kadunud.

${ }^{10}$ Finantsaruandluse rahvusvahelistes standardites ja Euroopa Liidu juhendmaterjalides on samas tähenduses kasutusel hoopis Briti termin finance lease, mida tuleks mõista kui finantseeritud renti(mist).

${ }^{11}$ Selleks on ka muid termineid. Näiteks väga levinud on termin shareholders' funds, mille tõlkevasteks ei ole muidugi aktsionäride fondid ega aktsionäride raha. 
vasteks annab kuuekeelne ärisõnastik stock capital'i (BCCSLBD 1991). See on sõnade tähendust arvestades ka igati loogiline. Kuna aktsiakapitali (stock capital) arvutamisel lähtutakse aktsiate koguhulgast (capital stock), siis ilmselt on ratsionaalsed ja laisavõitu ameeriklased hakanud terminiga capital stock tähistama nii aktsiate koguhulka kui ka aktsiakapitali. See võiks olla ka seletuseks, miks USA aktsiaseltside ${ }^{12}$ bilanssides on capital stock, mitte aga stock capital. Eeltoodut arvesse võttes tuleks USA äriühingute raamatupidamisbilanssides esinev capital stock tõlkida eesti keelde kui aktsiakapital hoolimata sellest, et nagu juba märgitud, rangelt originaali süntaksist lähtudes pole see õige. Siin tuleb arvestada mõiste sisu, pidades silmas võimalikku kaksiktähendust (capital stock $=$ stock capital).

Briti inglise keeles kasutatakse terminit capital stock suhteliselt harva ja hoopis teises tähenduses. Soliidne Oxfordi ärisõnastik (ODBW 1993) annab selle mõiste sisuks organisatsiooni põhivara (capital assets) kogusummas (aggregate). Mõnes sõnastikus täpsustatakse, et tegemist on ettevõttes, majandusharus või kogu rahvamajanduses rakendatud ainelise põhivara kogusummaga (Bannock jt 2003; Pass jt 1991). See on tõesti sõnaühendi capital stock tõlgendamise üks võimalus, seejuures keeleliselt absoluutselt korrektne - Briti inglise keeles tähendab stock eelkõige varu(sid). Viimast tuleks aga otsida hoopis raamatupidamisbilansi aktivapoolelt. Kokkuvõttes tuleb aga märkida, et nii Ameerika kui ka Briti inglise keeles on capital vaadeldavas sõnaühendis adjektiiv (tähenduses 'kogu-'). Võib ainult rõõmu tunda, et üleüldises kapitalieufoorias pole keegi püüdnud terminit capital stock tõlkida eesti keelde kui kapitalivaru(d) või kapitaliaktsiad.

Vaatleme nüüd lähemalt laialt levinud eesti liitsõna põhikapital. Nagu juba märgitud, kohtab nii ebaõnnestunud moodustist harva. Kõigepealt, põhikapital on sisuliselt topeltpõhi, kuna ladinakeelse capitālis'e nagu ka sellest lähtuva ingliskeelse sõna capital algne tähendus on 'peamine, põhiline'. Seega põhikapitali tõlkimisel inglise keelde võiks saada ka konstruktsiooni capital capital! Veelgi hullem on aga see, et moodustisega põhikapital on meil hakatud tähistama täiesti erinevaid ja (teatud mõttes) vastandlikke nähtusi. Tabelist 2 on näha, et kolmes vaadeldud sõnastikus on põhikapital ingliskeelse capital asset(s)'i eesti vaste ja viies ingliskeelse

${ }^{12}$ Kõrvalpõikena olgu märgitud, et USAs ja Suurbritannias osaühinguid pole. Ka väikesed äriühingud on aktsiaseltsid. 
capital stock'i eesti vaste. Seejuures kahes sõnastikus on mõlema ingliskeelse termini üks ühine eesti vaste põhikapital. Kunstlikult on tekitatud olukord, mis on põhjustanud (ja põhjustab edaspidigi) palju segadust inglise keeles ja mida eesti keeles on suudetud küllaltki edukalt vältida: nimelt sõnade polüs emantilisus. Jääb täiesti arusaamatuks, miks on tarvis nii süntaktiliselt kui ka semantiliselt ebakorrektse moodustisega põhikapital tähistada täiesti erinevaid nähtusi, mille jaoks teistes keeltes on eri oskussõnad olemas. Asja teeb eriti hulluks see, et meie raamatupidamisbilansis võib põhikapital olla nii aktivas (ingliskeelse capital assets'i eesti vastena) kui ka passivas (ingliskeelse capital stock'i eesti vastena). See on omal ajal põhjustanud halenaljakaid arusaamatusi isegi Eesti riigi kõrgemas juhtkonnas ${ }^{13}$.

Käesoleva artikli autor rõhutas juba 17 aastat tagasi, et tuleks loobuda segase liitsõna põhikapital kasutamisest majandusterminina. Seda peaksid tegema eelkõige majandusteadlased ja õppejõud - need, kes õpetavad ja konsulteerivad, kirjutavad raamatuid ja artikleid. Meie seadusaktidest on põhikapital nüüdseks kadunud, kuid nagu tabelist 2 võib näha, esineb see edasi inglise-eesti majandussõnastikes.

Mereste järgi võib oskussõnade tuletamises ${ }^{14}$ eristada kolme juhtu: „Esmaselt ja täiesti vabana teiste keelte mõjust tuletatakse termineid keeles, milles uutele mõistetele antakse nimetusi üldse esmakordselt. Teisese terminiloominguga on tegemist siis, kui teadusliku töö käigus tutvutakse teiste keelte piirkonnas väljakujunenud uute mõistetega ning püütakse neile leida oma keele süsteemi sobivaid nimetusi. Siingi lähtutakse mõistest, ent oskussõna valikut mõjustab oluliselt teine keel, milles uus mõiste on oma oskussõna saanud varem. Kolmandane terminituletus lähtub mingis võõrkeeles olemasolevast oskussõnast ja püüab leida sellele omakeelset vastet, ilma et selle mõistet täpselt teataks. See moodus on õigupoolest ebateaduslik, sest mõiste kui teaduse element jääb vaste valikul kas tahaplaanile või üldse kõrvale ja ekvivalentset seost püütakse leida ainult sõnade kui keeleelementide vahel" (Mereste 2000a: 85). Ja edasi: „,Kogu eestikeelne teaduslik sõnavara on saadud peamiselt teisesel ja kolmandasel teel; esmastekkeliste terminite osatähtsus on suhteliselt väike"

\footnotetext{
${ }^{13}$ Vt käesoleva kirjutise autori artiklit ,Savisaar portselanilaos ehk meie tipp-poliitikud ei tunne majandustermineid" (ajaleht Postimees, 30.03.1994).

${ }^{14}$ Merestel märgib sõna tuletamine sõnaloomet laiemalt kui üksnes tüvedest liidete abil uute sõnade moodustamist.
} 
(Mereste 2000a: 85). Kahjuks tuleb nentida, et pärast taasiseseisvumist on eestikeelseid majandustermineid loodud valdavalt kolmandasel teel. Sellest annab tunnistust üldise keelekultuuri langusega kaasnenud mõttetute sõnaühendite kasutamine oskussõnadena ja (peamiselt inglise keelest pärit) toortõlgete suur hulk, mida on käsitletud ka käesolevas artiklis.

\section{Kokkuvõtteks}

Kuigi artikkel on pühendatud sõna kapital sisaldavate ingliskeelsete majandusterminite tõlkimisele, ei saa vaikimisi mööda minna emakeelse majandusterminoloogia kurvast hetkeseisust. Eesti taasiseseisvumisega saabunud turumajandus tekitas olukorra, kus tuli kiires korras hakata looma uut eestikeelset oskussõnavara. Kuigi nõukogude aja lõpuks oli eestikeelne majandusterminoloogia tänu sellistele tugeva keelevaistuga majandusteadlastele nagu akadeemikud Uno Mereste ja Raimund Hagelberg, professorid Raoul Üksvärav, Erik Linnaks, Eduard Kull, Vello Volt jpt hästi välja arendatud, olid paljud turumajandusele olulised oskussõnad kas ununenud või üldse loomata. Kahjuks oli vana kaardivägi selleks ajaks juba taandumas, meie majandusteadlaste ja keeleinimeste noorem põlvkond pole aga kuigi entusiastlik majanduse oskussõnavara arendama. Enamgi veel: mitmed märgid näitavad, et korrektse emakeelse majandusterminoloogia loomist ja arendamist ei väärtustata. Tahaks loota, et niisugune olukord on ajutine, langusele järgneb jälle tõus ning emakeelse oskussõnavara loomine ja arendamine saab majandusteadlaste ja keeleinimeste ühismureks ja -ettevõtmiseks. Lõpetuseks ka üks konkreetne soovitus: vältige sõna kapital kasutamist niipalju kui võimalik.

\section{Kirjandus}

Adam, J. H. 1991. Longman Dictionary of Business English. $2^{\text {nd }}$ edition. Beirut: York Press.

Alver, Jaan 1998. British and American Business Terms: Avoiding Costly Understandings. Tallinn: Deebet.

Banks, Erik 2010. The Palgrave Macmillan Dictionary of Finance, Investment and Banking. Palgrave Macmillan.

Bannock, Graham, William Manser 1990. Penguin International Dictionary of Finance. London: Penguin Books.

Bannock jt 2003 = Graham Bannock, Ron E. Baxter, Evan Davies. The Penguin Dictionary of Economics. $4^{\text {th }}$ edition. London: Penguin Books. 
BCCSLBD 1991 = British Chambers of Commerce Six Language Business Dictionary. Cambridge: Colt Books.

Brockington, Raymond 1993. Dictionary of Accounting and Finance. London: Pitman Publishing.

BT 1991 = Banking Terminology. American Bankers Association. $3^{\text {rd }}$ revised edition.

Cannan, Edwin 1921. Early history of the term capital. - Quaterly Journal of Economics. Vol. 35, No. 3, 469-481. doi:10.2307/1884097.

Capital: Word History. http:// word-origins.com/definition/capital.htm (30.12.2010).

Caruth, Donald L., Steven Austin Stovall 1994. NTC's American Business Terms Dictionary. Lincolnwood: National Textbook Company.

CDB 1991 = Concise Dictionary of Business. Oxford: Oxford University Press.

Crumbley jt 1994 = Donald Larry Crumbley, Jack P. Friedman, Susan B. Anders. Dictionary of Tax Terms. New York: Barron's.

Davids, Lewis E. 1986. Instant Business Dictionary. Mundelein: Career Publishing.

DBM 2003 = Dictionary of Business and Management. London: Bloomsbury.

DF 1993 = Dictionary of Finance. Oxford: Oxford University Press.

Downes, John, Jordan Elliot Goodman 2006. Dictionary of Finance and Investment Terms. $7^{\text {th }}$ edition. New York: Barron's.

EE 1934 = Eesti Entsüklopeedia. 4. köide. Peatoim. Richard Kleis. Toim. Peeter Treiberg, Johannes Voldemar Veski. Tartu: Loodus.

EKSS 2009 = Eesti keele seletav sõnaraamat. 2. köide (K). „Eesti kirjakeele seletussõnaraamatu" 2., täiendatud ja parandatud trükk. Toim. Margit Langemets, Mai Tiits, Tiia Valdre, Leidi Veskis, Ülle Viks, Piret Voll. Eesti Keele Instituut. Tallinn: Eesti Keele Sihtasutus.

ENE 1971 = Eesti nõukogude entsüklopeedia. 3. köide. Tallinn: Valgus.

ENE 1989 = Eesti Nõukogude Entsüklopeedia. 4. köide. Tallinn: Valgus.

ERL 1937 = Eesti rahvaleksikon. Tartu: Noor-Eesti Kirjastus.

EVS 1937 = Herbert Haljaspõld. Entsüklopeediline võõrsõnastik. 3., täiendatud trükk. Tallinn: Raamat.

Friedman, Jack P. 2007. Dictionary of Business Terms. $4^{\text {th }}$ edition. New York: Barron's.

Godfrey, Jayne Maree, Alan J. Robb 1997. Australian Dictionary of Accounting and Finance Terms. $2^{\text {nd }}$ edition.

Greener, Michael 1999. The Penguin Business Dictionary. London: Penguin Books.

Haljaspõld, Herbert 1935. Ärielu manuaal I. Kaubanduslik terminoloogia koos saksakeelse võtmega. Tallinn: Tarbeteos. 
Hammett, Mike 2001. Dictionary of International Trade Finance. Kent: Financial World Publishing.

HFD 2007 = Harriman's Financial Dictionary. Ed. Simon Briscoe, Jane Fuller. Hampshire: Harriman House.

IEEIÄS 1993 = Inglise-eesti ja eesti-inglise ärisõnastik. Koost. Andres Aule, Erik Jõgi, Henri Toompere. Tallinn: Keelefirma TEA.

IEMS 1995 = Inglise-eesti majandussõnaraamat. Koost. Vahur Raid. Toim. Ants Pihlak. Tallinn: TEA.

IEMSS 2007 = Inglise-eesti majandusterminite seletussõnaraamat. Koost. Vahur Raid. Tallinn: Kirjastus Ilo.

IEMTS 1990 = Inglise-eesti majandusterminite sõnastik. (= A. M. Freeman. Mikroökonoomika baasteooria. 5. osa.) Tallinn: Eesti Majandusjuhtide Instituut.

IEMTSS 1992. Inglise-eesti majandusterminite seletussõnastik. Toim. Uno Mereste. Tallinn: Eesti Majandusjuhtide Instituut.

IERSS 1994 = Inglise-eesti raamatupidamisterminite seletussõnastik. Toim. Erik Linnaks. Majandusraamat 2-20. Tallinn: Külim.

Inno, Karl 1938. Pangandamistehnika. Tartu.

LDFT 2008 = Longman Dictionary of Financial Terms. Ed. Nixon K. Kariithi. Cape Town: Pearson Education South Africa.

Mereste, Uno 2000a. Oskuskeele korraldamise mõningaid üldpõhimõtteid. Uno Mereste. Oskuskeel ja seaduste keeleline rüü. Artikleid ja lühiuurimusi. Eesti Keele Sihtasutus, 84-88.

Mereste, Uno 2000b. Terminoloogilise liitsõnamoodustuse semantilisi aluseid. - Uno Mereste. Oskuskeel ja seaduste keeleline rüü. Artikleid ja lühiuurimusi. Eesti Keele Sihtasutus, 175-217.

Mereste, Uno 2003. Majandusleksikon. I köide (A-M). Toim. Ülo Mallene. Tallinn: Eesti Entsüklopeediakirjastus.

MEVS 2008 = Minu esimene võõrsõnastik. Tallinn: TEA.

Mooney, Kate 2008. Essential Accounting Dictionary. Naperville: Sphinks Publishing.

MTABC 1985 = Majandusteaduse ABC: majandusleksikon kõigile. Koost. Uno Mereste. Tallinn: Eesti Raamat

Munn jt 1993 = Glenn G. Munn, F. L. Garcia, Charles J. Woelfel. Encyclopedia of Banking \& Finance. $9^{\text {th }}$ edition. Chicago: Probus Publishing.

OBED 2008 = Oxford Business English Dictionary. Ed. Dilys Parkinson. Oxford: University Press.

ODBE 1993 = Oxford Dictionary of Business English for Learners of English. Ed. Allene Tuck. Oxford: Oxford University Press.

ODBW 1993 = Oxford Dictionary for the Business World. New York: Oxford University Press. 
Pass jt 1991 = Christopher Pass, Bryan Lowes, Leslie Davis, Sidney J. Kronich. The Harper Collins Dictionary of Economics. New York: Harper Perennial.

Renton, Nicholas Edwin 2008. Renton's Dictionary of Stock Exchange and Investment Terms. Seaford Vic: Bas Publishing.

Ricci, Julio 1990. Elsevier's Banking Dictionary (in seven languages). $3^{\text {rd }}$ edition. Amsterdam: Elsevier.

Richards, R. D. 1926. Early history of the term capital. - Quaterly Journal of Economics. Vol. 40, No. 2, 329-338.

Rosenberg, Jerry M. 1986. Investor's Dictionary. New York: John Wiley \& Sons.

Rosenberg, Jerry M. 1993. Dictionary of Business and Management. New York: John Wiley \& Sons.

Samuelson, Paul Anthony, William Dawbney Nordhaus 1989. Economics. $13^{\text {th }}$ edition. New York: McGraw Hill.

Scott, David L. 2009. American Heritage Dictionary of Business Terms. Boston New York: Houghton Mifflin Harcourt.

Schäfer, Wilhelm 1990. Financial Dictionary. Teil I: English-Deutsch. München: Deutscher Taschenbuch Verlag.

Shook, Robert James, Robert Shook 1990. The Wall Street Dictionary. New York: New York Institute of Finance.

Siegel Joel G., Jae K. Shim 2005. Dictionary of Accounting Terms. $4^{\text {th }}$ edition. New York: Barron's.

SIEMS 2003 = Suur inglise-eesti majandussõnaraamat. Estonian-English Dictionary of Economics. Koost. Andres Arrak, Lauri Luiker, Avo Org, Mare Randveer, Ahti Tomingas. Toim. Ruth Mägi, Lea Noorma. Konsultandid: Gert Antsu, Karin Sein. Tallinn: TEA.

Steer, Margaret 1990. Dictionary of Business Studies. London: Pitman.

TA 1992 = Terminology for Accountants. $4^{\text {th }}$ edition. Toronto: The Canadian Institute of Chartered Accountants.

TEARS 2006 = TEA RAHVASÕNARAAMAT: Võõrsõnad. Tallinn: TEA.

Toots, Aet, Jaan Alver 2008. Dictionary of Accounting Terms: English-EestiFrançais-Deutsch. Tallinn: Deebet.

UIEMS 1999 = Uus inglise-eesti majandussõnaraamat. Koost. Vahur Raid. Tallinn: Festart.

VE 1938 = Väike entsüklopeedia. 4. köide. Tartu: Loodus.

VE 2006 = Väike entsüklopeedia. Peatoim. Rein Aro. Tallinn: Eesti Entsüklopeediakirjastus.

VL 1930-1931 = Võõrsõnade leksikon. I-VIII. Koost. Herbert Haljaspõld. Tallinn: Kirjastus Elu.

VL 1961 = Võõrsõnade leksikon. Koost. Richard Kleis, Johannes Silvet, Eduard Vääri. Tallinn: Eesti Riiklik Kirjastus. 
VL 1981 = Richard Kleis, Johannes Silvet, Eduard Vääri. Võõrsõnade leksikon.

4. trükk. Tallinn: Valgus.

VL 2006 = Eduard Vääri, Richard Kleis, Johannes Silvet. Võõrsõnade leksikon. Seitsmes, parandatud ja täiendatud trükk. [Tallinn:] Valgus.

VMO 1935 = Valimik majanduslikke oskussõnu. Tallinn: Eesti Tarvitajaühisuste Keskühisuse Kirjastus.

VS 2005 = Võõrsõnastik. 2., täiendatud ja ümbertöötatud trükk. Tallinn: TEA Kirjastus.

VSM 2009 = VÕÕRSÕNASTIK: MINI. Tallinn: TEA.

VVS 1933 = Herbert Haljaspõld. Väike võõrsõnastik. Tartu: Noor-Eesti Kirjastus.

Wallace, Michael J., Patrick J. Flynn 1989. Collins Business English Dictionary. London: Collins Educational.

Wanjialin, Guy 2004. An International Dictionary of Accounting \& Taxation. Lincoln: iUniverse.

Wuite, Rudy 2009. South African Dictionary of Finance. Northcliff: Rollerbird Press.

ÕS 1999 = Eesti keele sõnaraamat ÕS 1999. Toim. Tiiu Erelt. Koost. Tiina Leemets, Sirje Mäearu, Maire Raadik ja Tiiu Erelt. Eesti Keele Instituut. Tallinn: Eesti Keele Sihtasutus.

ÕS 2006 = Eesti õigekeelsussõnaraamat ÕS 2006. Toim. Tiiu Erelt. Koost. Tiiu Erelt, Tiina Leemets, Sirje Mäearu, Maire Raadik. Eesti Keele Instituut. Tallinn: Eesti Keele Sihtasutus. 


\title{
About translation of English economic terms including the word capital into Estonian
}

\author{
Jaan Alver
}

The paper focuses on the translation of economic terms from English into Estonian, including the word 'capital'. The paper provides an overview how a word of Latin origin became an adjective, noun, and verb with multiple meanings. Also, one can find a short overview of how 'capital' developed into a business and economic term. The paper discusses on the basis of specialized EnglishEstonian dictionaries published in Estonia the content and accuracy of the Estonian equivalents of two-word English business and economic terms, such as 'capital goods', 'capital lease', etc.

Keywords: Estonian language, English language, terminology, translation, capital

\author{
Jaan Alver \\ majandusarvestuse instituut \\ majandusteaduskond \\ Tallinna Tehnikaülikool \\ Akadeemia tee 3 \\ 12618 Tallinn \\ jaan.alver@ttu.ee
}

